\title{
JURNAL NATAPRAJA:
}

\section{Kajian Ilmu Administrasi Negara}

2406-9515 (p) / 2528-441X (e) https:/ /journal.uny.ac.id/index.php/natapraja

\section{Micro, Small, And Medium Enterprises (MSMEs) Empowerment Through Quadruple Helix Approach in Batu City}

Lely Indah Mindarti ${ }^{1}$, Ajie Hanif Muzaqi

Faculty of Administrative Science, Universitas Brawijaya, Indonesia

\section{ARTICLE INFO}

Article history:

Received 18 July 2020

Received in revised form 21

October 2020

Accepted 28 November 2020

\section{ABSTRACT}

In order to address the problem of unemployment and poverty, the Batu City Government has established the empowerment and development of MSMEs. Although the existence of MSMEs in batu has increased, this condition is not in line with the decline in unemployment..The research purpose is to describe implementation of MSMEs empowerment in Batu using the perspective of Quadruple helix model. This research uses a descriptive qualitative approach. The Government of Batu through the Department of Micro Enterprise Cooperatives and Trade of Batu implements MSMEs empowerment by relying on 4 main factors of empowerment: financial capital access, human resource, partnership, and market strengthening. This government also established Integrated Business Service Centre (IBSC) as one of the commitments in empowering MSMEs and also making Batu as MSMEs centre. The result of analysis using the concept of Quadruple helix model found that MSMEs empowerment in Batu involves collaboration of different sectors: the government of Batu, private/business institutions, academics, and civil society through communities, groups, and non-governmental organizations. Thus, the government of Batu plays dominant roles in the interaction synergies of different sectors and being responsible in equitable economic development. Private institutions play roles as production developer, academics play roles as knowledge and skill development transferor and civil society plays roles as creative economic agents and product users.

Keyword:

Empowerment; MSMEs;

Quadruple helix model

\footnotetext{
${ }^{1}$ lelyfia@ub.ac.id 


\section{INTRODUCTION}

Government plays important roles in directing the independence of prosperous society as one of sustainable development purposes. Equitable and fair usability principle must be held firmly in order to create planned development, oriented on society welfare and national awareness based on national development purposes (Effendi, 2002:114). Development itself is categorized in two, they are: physical and non-physical development (Suryono, 2010:31). Physical development is more focused on the facility aspects, whose benefits can be directly felt, while nonphysical development is the development that becomes the base of physical development itself, by putting forward the development that is oriented on social aspects.

Society involvement in the effort of increasing development, especially the development in the economic field could become serious attention for the government. It needs efforts; one of them is by empowering small communities, because the economic strength of one country can be measured from the improvement and the equalization of the society's income. Society as the main actors in economic development indirectly must be able to be pushed to be independent and creative in generating products because it does affect the national development acceleration. In order to create equitable income and job vacancies, the existence of small and medium enterprises of the society will become the opportunity to accelerate economic development. One of the means in increasing society income is by establishing Micro, Small, and Medium Enterprises (MSMEs) that are well empowered and developed by all stakeholders. According to the mandate in article 2 of Government Regulation No. 20/2008 about Micro, Small, and Medium Enterprises (MSMEs), it indicates that an area needs to develop MSMEs through planned programs and involve the society in national economic development sustainability.

Based on Local Regulation of Batu Number 1, 2016 about MSMEs empowerment and development, it is stated that MSMEs in Batu are able to become an alternative solution of the economic gap problems, such as unemployment and poverty. MSMEs development in Batu has also become a positive trend since 2012 until 2016 that MSMEs numbers has increased from 13.361 to 14.579 (BPS Kota Batu, 2017). It surely needs to be more developed and empowered. On the other hand, Batu has a problem in the unemployment sector. From 2013 to 2016 , the number of unemployment in Batu had increased from 2.421 to 4.700. That condition was not in line with the MSMEs development. This can be a problem that must be soon solved. Government's role is needed in supporting MSMEs empowerment that is based on the local potency, because it would have effect on the job vacancies availability, would become a solution of the problems faced by entrepreneurs, and would show the real condition of MSMEs in Batu. Besides, it also needs review of other actors' roles in integrating their functions through Quadruple helix model that also has function for economic empowerment from MSMEs sector. Based on the background, the researchers were interested in conducting a research entitled "Micro, Small, and Medium Enterprises (MSMEs) Empowerment through Quadruple helix Approach (A Study at Department of Micro Enterprise Cooperatives and Trade in Batu City)". MSMEs empowerment implementation in Batu is seen from Quadruple helix perspectives which are based on; 1) MSMEs empowerment process in Batu; 2) The roles of Quadruple Helix actors in MSMEs empowerment in Batu; 3) 
The pattern of synergy and interaction of each Quadruple Helix actors.

\section{METHODS}

The type of this research is descriptive research with a qualitative approach. Moleong (2006:6) states that descriptive research with qualitative approach is research that shows real facts about an object, symptoms, and circumstances by description, drafting, explaining, and interpreting in a conclusion and in a form of systematic writing. The objectives and the focuses of this research are How MSMEs empowerment in Batu, contained (1) The roles of Quadruple Helix actors in MSMEs empowerment in Batu, (2) The pattern of synergy and interaction among each Quadruple Helix actors.

The location of the research chosen by the researchers is the Department of Micro Enterprise Cooperatives and Trade of Batu City. The research sites are: Department of Micro Enterprise Cooperatives and Trade of Batu City, MSMEs, Integrated Business Service Centre (IBSC), and stakeholders that hold business licenses and are legally registered in the department. Data sources are divided into three, they are: (1) informants include: Head of Micro Enterprises (ME) and Small and Medium Industry (SMI) Division; Head of Micro Enterprises Empowerment Section; Head of ME and SMI Development Section; Head of Programs and Reports Sub Section; Cooperatives Empowerment Staff; IBSC Supervisor; Batu City Citizens; Businessmen/Business Agent; Academics; and Bank Institutions. Data collection is conducted using observation, interview, and documentation. The research instruments are the researchers themselves, interview guidelines, field notes, and other supporting devices. Data analysis is conducted using Miles, Huberman and Saldana model data analysis. Miles, Huberman dan Saldana (2014:8) states that there are four stages: data collection, data condensation, data presentation, and conclusion.

\section{RESULT AND DISCUSSIONS}

Empowerment and Quadruple Helix

Empowerment is an effort to increase society welfare. According to Anomsari \& Abubakar (2019) empowerment can be seen as a public awareness process about the reality they face and increase their capability to bring change to that reality. Chambers in Theresia, et.al. (2014:91) society empowerment is an economic development concept that summarizes social values. This concept reflects a new development paradigm that has several characteristics, they are: people-centered, participatory, empowering, and sustainable. Furthermore, according to Theresia, et.al. (2014: 93) conceptually, society empowerment is an effort to increase the dignity of the society who recently is not able to escape from the trap of poverty and retardation. In other words, to empower means to enable and to make society more independent.

Another opinion is stated by Latama in Zubaedi (2007a:99) who explains that society empowerment is designed and conducted thoroughly. Society empowerment is considered comprehensive if it has these characteristics; they are:Local-based, Welfare increase oriented, Partnershipbased, Holistic-based, and Sustainable. So, the concept of empowerment involves all important aspects in society life. Moreover, in order to succeed the empowerment program; participation, individual awareness, society and community support are needed

In line with Theresia, et.al. (2014:94) who states that empowerment is an effort to make a community more independent by creating the potential ability owned by the community itself. Empowerment basically is a way for society to be able to control its own life. And, the empowerment concept is 
included in the society development related to concepts of independency, participation, networking, and equalization (Craig and Mayo, 1995 in Huraerah, 2008:82). Soetarso (2003) in Huraerah (2008) explains that society empowerment concept essentially has two meanings that are related to each other, they are (1) Improvement of ability, motivation, and roles of all society elements in order to become a main source to support all types of enterprises and society welfare, (2) The use of society resource that has been given comprehension and information in order to improve their ability, motivation, and roles.

MSMEs meaning according to the consensus of German Agency Far Technical Cooperation (2002) in Bank of Indonesia (2010:9), there are two purposes regarding a clear definition of MSMEs, that is for administrative and regulation purposes and supervising related purposes. The first purposes are related to regulation that requires a company to fulfill its obligations, such as; pay the tax and obey the employment regulation and other workers' rights. Whereas, the second purpose is more focused on the directed policy making, such as: supervising effort, ability improvement, and MSMEs financial policy.

According to Dewantoro (2001:157158), empowerment concept especially in MSMEs fields, all this time, focuses on structural steps, such as: business capitalization retribution, licensing deregulation, and so on. Dewantoro (2001) also adds that society economic empowerment must be more comprehensive and effective; and improvement in MSMEs field should also involve cultural aspects, in this case is the mentality of work ethic.

MSMEs empowerment is conducted by developing MSMEs. Khamarullah (2014) states that the stages in developing MSMEs must involve these aspects, they are (1) Access improvement for productive assets, especially financial capital, besides technology, management, and other aspects, (2) Knowledge and skills training that is really needed and entrepreneurship passion enactment, (3) Economic institutional in a board meaning is market. Strengthening the market is very important along with controlling it, in order to make the running process of the market will not be out off track that later can cause a gap. Therefore, suitable interventions; that are not against the basic rules of free economy and ensure social equity; are needed, (4) Enterprise partnership is an important and strategic way and has been proved to succeed in developing society economic enterprises.

Empowering society's small and medium enterprises needs integration between government as the policy agent and society as the businessmen/business agent. In empowering MSMEs, the businessmen also need to be empowered because they play an important role in MSMEs empowerment.

Quadruple Helix concept, according to Mulyana (2014:8) is a concept that collaborates four sectors, they are; government, business, academics, and civil society that aims to push the development of innovation, so that it can support the country's success in implementing the development. In the concept of Quadruple Helix, each sector involved plays important roles, such as private institutions (business) that play roles as the business agent/ businessmen, investor, technology generator, and creator that takes products from and distributes them to civil society. Next, academics play roles in improving technology innovation capability that later would be transferred toward creative industry business agents. Civil society plays roles in producing creative products that can activate economy flow. And, the government plays important roles in transferring knowledge, technology, and innovation; and also in supervising and 
empowering to improve creative industry by controlling all sectors in order to hold the principle of fairness and equalization (Dewi, 2009:9).

Quadruple Helix concept is directed to the production side, high technology sector, resource development, financial capital access opening, and integration among government, business, academics, and civil society. Quadruple Helix Innovation Theory aims to pay attention to the innovation mechanism, economic development, and productivity or technology. Civil society plays an important role as an environmentally friendly's market supporter through lifestyle changing, consumption behavior, participation in organizational regulation that can activate social and organizational innovation and the strength of business agent relationship in creative industry that would create creativity and innovation through community and supply chain

\section{MSMEs Empowerment Implementation in} Batu

The Department of Micro Enterprise Cooperatives and Trade of Batu City implements MSMEs empowerment by relying on four main factors of empowerment, they are: financial capital access, human resources, partnership, and market strengthening. Empowerment through financial capital access is prioritized for MSMEs that has just established new business, while for MSMEs that have already operated for more than five years are considered independent to fulfill their capital needs. Financial empowerment implemented by the government of Batu City is by opening Bank loan access and by giving soft loan with light installment and interest payment. Furthermore, the second empowerment strategy focuses on human resources. The government of Batu City implements empowerment by giving guidance and assistance related to production methods up to marketing, by involving all sectors, such as: MSMEs trainers, motivators, online media experts, MSMEs examples, and other stakeholders to give guidance and assistance related to financial management, production techniques, marketing methods, up to strategic plan to improve MSMEs in the future. The government of Batu City also gives empowerment facilities for MSMEs agents through Integrated Business Service Centre (IBSC) that is in charge to give guidance and assistance related to consultation, production, MSMEs training, and helping the process of MSMEs products marketing.

Besides the empowerment that focuses on financial capital access and human resources, the government of Batu City also implements empowerment through partnership by cooperating with all different sectors. It is done because the Department of Micro Enterprise Cooperatives and Trade also has limitations in implementing MSMEs empowerment. Empowerment through partnership is implemented by involving private corporations, experts, stakeholders, MSMEs agents' community, and other sectors. Empowerment through partnership is conducted to make MSMEs agents independent in implementing financial management, production, and marketing; to keep innovating; and to be able to use information technology in conducting marketing. Moreover, the last focus in empowering MSMEs is empowerment through market strengthening. The government of Batu City has established Integrated Business Service Centre (IBSC) that is in charge to give counselling to MSMEs beginners; to give financial capital access, empowerment, and assistance; and to help MSMEs local products marketing in Batu. Market strengthening effort through product marketing is frequently conducted through exhibitions and other events in 
Batu or in other cities and provinces. Market strengthening is also supported by the regulation of Batu City Mayor that gives flexibility for MSMEs agents to market their products in hotels, tourism objects, and other public places.

Based on the result of the research, there are many MSMEs in Batu that have succeeded and been independent in fulfilling their needs related to financial capital and marketing. One of them is Brosem and Olive House of Batik gift shop. According to Head of Industry Division of Department of Micro Enterprise Cooperatives and Trade of Batu City, several MSMEs have indeed been independent financially by implementing some strategies, for instance, by opening Batik and gift shop with the concept of a café inside the shop that has been done by Brosem and Olive House of Batik gift shop. This marketing method has succeeded in attracting the local society to visit and shop. Moreover, the profit from café and souvenirs can cover up the capital of Batik sales, so the capital can be renewed; and it can also make the business become financially independent. MSMEs as Brosem and Olive House of Batik gift shop should be a good MSMEs example in Batu.

Actors Roles Based on Quadruple Helix Concept in MSMEs Empowerment in Batu Government Roles

The government of Batu City through the Department of Micro Enterprise Cooperatives and Trade of Batu City implements MSMEs empowerment that focuses on four aspects, they are: financial capital access, human resources, partnership, and market strengthening. In this case, the Department of Micro Enterprise Cooperatives and Trade divides two sectors, there are trade and Micro Enterprises Sector. The First, Trade Sector has several roles such as (1) The Opening of Information and Technology-Based Market Access. It is done in order to increase Batu MSMEs market access by giving web-based information and technology facilities. The City Government that is initiated by the Department of Micro Enterprise Cooperatives and Trade cooperated with a private institution that is Telkomsel, to broaden web-based telecommunication network in order to upgrade MSMEs income from internetbased sales; (2) Marketing Strategy. Local Government of Batu City organizes exhibitions and activity programs that support local MSMEs agents that are held regularly every year. Wearing Batu typical Batik is compulsory for government employees and must be worn every Thursday. And, products marketing that are supported manually by Integrated Business Service Centre (IBSC) or via web site online, such as plutkumkmbatu.blogspot.co.id; (3) Partnership-As an effort of MSMEs empowerment, Local Government of Batu City has tied partnership with Bank of Indonesia, PT Telkom, Garuda Indonesia, and Department of East Java Province. This type of partnership aims to market the products, training, and supervision in the scope of area among middlemen to foreign countries that help Batu MSMEs products marketing, such as apple chips, and other fruit chips.

The Second, Micro Enterprises have roles such as (1) Sector New Businessmen Supervision-It is done through a supervision agenda series that is integrated and sustainable in order to improve Batu MSMEs potency; and this program is conducted through workshop, training, and comparative study by dispatching MSMEs agents to the areas where the MSMEs are independent. It is done to maintain Batu MSMEs as tourism commodity; (2) Micro and Small Businessmen Supervision. It is done by giving training about work skill and interesting product designs. IBSC that is provided by the Local Government of Batu 
City is a means and a facility that is given to MSMEs agents in order to train on how to create a competitive product and how to package products interestingly (3) Capital Loan Providing. Local Government of Batu has been trying to empower the society who is running businesses, such as giving them capital access. There are several capital sources that Batu Local Government has been trying to provide, one of them by involving Banks through soft loan credit.

In line with the mandate from Constitution and instruction from central government, State-Owned Enterprises along with Bank Rakyat Indonesia (BRI), Bank Tabungan Negara (BTN), and Permodalan Nasional Madani (PNM) have committed to distribute fund for MSMEs with easy arrangement and installment payment; and light interest.

One of State-Owned Enterprises that has cooperated is PT Telekomunikasi Indonesia especially in generating technology and using internet in the business world; and Garuda Indonesia that is sheltered by the Department of Tourism also takes a part in promoting tourism and MSMEs products of Batu.

The cooperation conducted by the Department of Micro Enterprise Cooperatives and Trade of Batu City with the community actors in empowerment programs is as a planning organizer and actor who uses the product and service of the local economy. In improving human resources quality, creating a young entrepreneur community can be a good place for entrepreneurs in that area to share and motivate each other. For entrepreneurs that have reached independence level will possibly give their dedication form to the other businessmen by helping each other in improving their products quality.

Besides improving production quality and human resources of the businessmen themselves, civil society also conducts cultural programs that aim to protect the assets of local products. Cultural programs here means cultural and local products exhibitions. Even though its intensity is not as regular as Malang City, which is Malang Tempoe Doeloe. Moreover, this community also plays roles in creating different products. Batu itself has several entrepreneur communities in a form of organization. However, they are not really organized well, so those organizations are inactive. With the service facility for MSMEs agents that is The IBSC building, it is hoped that businessmen in those communities can give information and help morally and psychologically to each other. Therefore, those businessmen communities can be more creative and innovative in creating products.

Based on the researchers finding in the field, especially about the intellectual and academics roles in developing MSMEs in Batu, it focuses on two important things, they are: The first, giving materials about entrepreneurship management and utilizing financial knowledge in order to organize the organization's finance; second, utilizing technology in order to resolve the waste and economize the raw materials. However, studies conducted individually such as bachelor degree essay, thesis, or dissertation can also be classified as community service and it is hoped that the result of the studies would give a big effect on issues in the society.

\section{The Synergy Pattern of Quadruple helix Actors in MSMEs Empowerment in Batu}

Quadruple helix model concept that involves the elements of government, civil society, private institutions, and academics focuses on human capital principle in MSMEs empowerment. It is also explained by Mulyana (2014) that the Quadruple helix approach emphasizes innovation capability and regional competitiveness in the context of creative industry empowerment. With MSMEs agents' empowerment, it is hoped that creative 
industry development in Batu can be one of the supporting aspects of economic society in Batu. By considering principles in human capital, Quadruple helix approach is empowerment media that has the most dominant effect. It is because
Moreover, synergy patterns formed by the government along with the business are: Financial Intermediation, Business Innovation Development and Carriage Locomotive System (Big Companies Pull Small Businessmen).

\section{Figure 1. Quadruple helix concept}

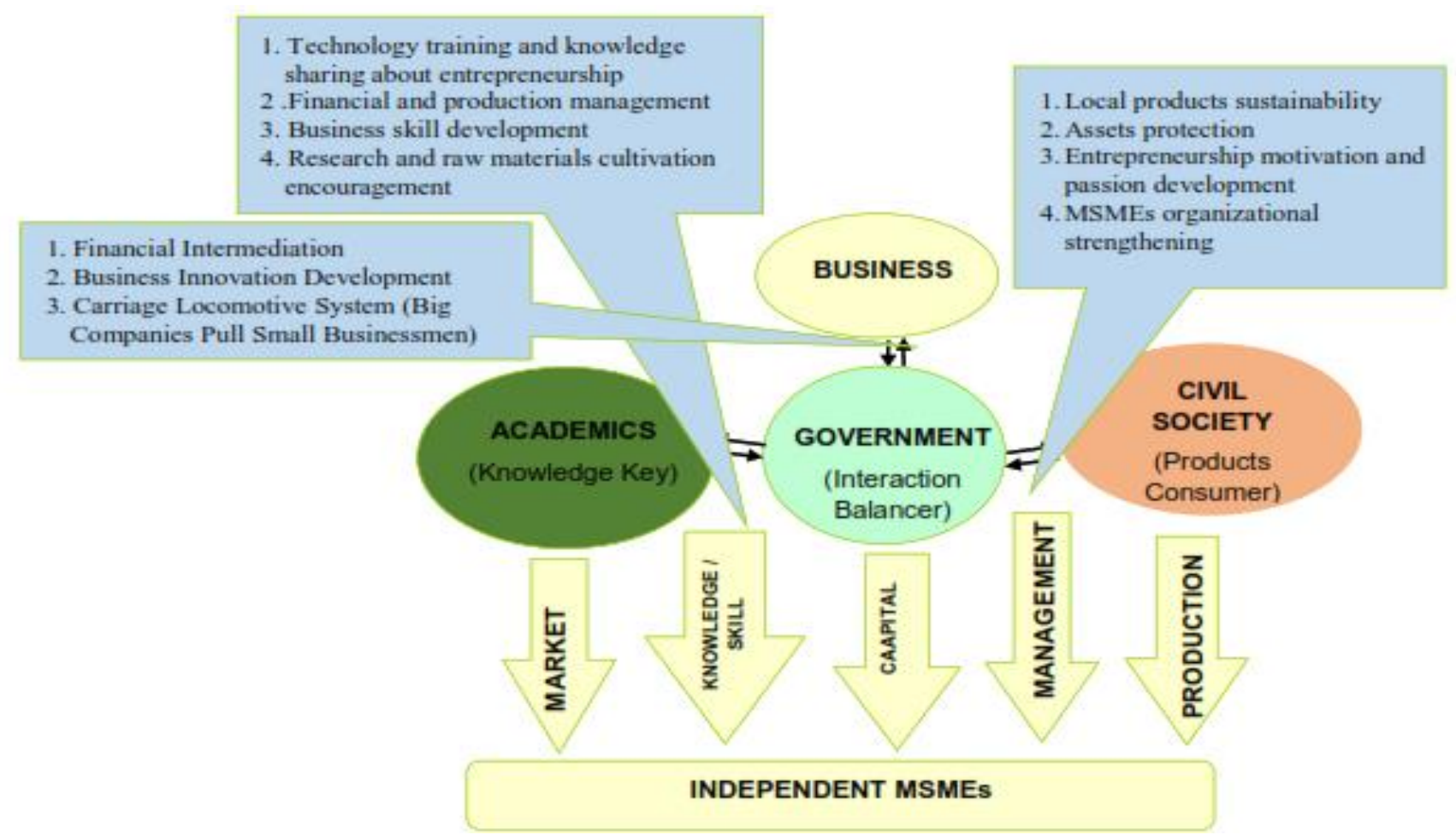

Source: author

Quadruple helix focuses on human empowerment to minimize local economic gaps. It can be concluded that the Quadruple helix model approach is strategy formulation to reduce the number of poverty in a region and to increase its local economic development. There are interaction patterns that involve four actors in the Quadruple helix method. It can be seen from the picture below:

Based on the picture above, the interaction pattern of all sectors involved in the Quadruple helix concept can be understood clearly. There is cooperation between different sectors that is hoped to be able to raise the economy in Batu through independent MSMEs empowerment. The cooperation between government, business, academics, and civil society can be seen in the picture above.
It cannot be denied that business/private sectors roles in the economy of Batu do dominate. By carrying the concept of the tourism industry, Batu requires individual competition in the economy flow. In order to form a strong and competitive competitiveness, the government must pay more attention to independent MSMEs competitiveness. Through quadruple helix interaction concept happening in Batu, the government must be able to build partnership with business sectors as partners in MSMEs empowerment programs. The majority of developed private sectors that do not take society's side should not be considered as a gap by the local government. That circumstance should make the government more proactive in cooperating in order to obtain 
more benefits for the society. The more regions are affected by industrial competition, the more its local investment (Dewi, 2009).

Other actors that interact through cooperation with the government are academics. Batu City is close to Malang City. There are two big universities in Malang that always cooperate with the local government in empowering MSMEs. Those two universities are University of Brawijaya and University of Muhammadiyah Malang. There are also other universities that cooperate with each other. According to Mulyana (2014) intellectuals' roles need to be considered as a component that transfers creativity and technology. Intellectual academics are able to improve innovation capability. Universities play an important role in innovation as much as industry and government in society. Knowledge and technology transferring is very useful for businessmen who still use traditional ways because by using technology, they can do everything related to their business more easily and faster. Besides, with the research and knowledge obtained, academics will distribute their knowledge innovation more easily to be implemented in local society in order to fulfill their universities tri dharma requirements: research, service, and teaching. For the MSMEs empowerment in Batu context, intellectuals and academics who have already implemented their knowledge for research and services consist of different intellectuals. With their bachelor degree essay, thesis, and dissertation; these intellectuals element share their knowledge for businessmen capacity improvement, especially in the field of production management and finance. Meanwhile, the context of cooperation between the government and academics in MSMEs empowerment specifically has several benefits, such as technology training and knowledge sharing about entrepreneurship, financial and production management, Business skill development, Research and raw materials cultivation encouragement.

The next is the Quadruple helix interaction and coordination pattern between the government and civil society. In the context of Quadruple helix, civil society here has two categories, they are: products and services users; and businessmen community (Mulyana, 2014). There are some incorporated civil societies in Batu and some are not. (Mulyana, 2014) states that civil society actors have a big effect on crafting industry improvement. It is because those actors will become product communication activators in developing the consumption of local MSMEs products that are produced by local businessmen. Besides, those actors can become a potential consumer to develop pride in their own country's products. Based on the result of the analysis in the field, the cooperation between the government and civil society would result in several benefits for businessmen empowerment, such as: local products sustainability, Assets protection, Entrepreneurship motivation and passion development, and MSMEs organizational strengthening.

Through the Quadruple helix model concept that involves the interaction among four sectors; intellectuals, government, business and civil society; will be able to improve creativity and result in fair and equitable economic development. Based on the result of the research, the government of Batu plays a dominant role in MSMEs empowerment through Quadruple helix model concept. The government's position in the middle among the empowerment actors shows the government's domination in organizing and managing the synergy of each sectors' interaction involved. The economic development of private companies and the increase of MSMEs number every year 
must be able to be balanced with policy and commitment of the government in order to ensure the availability of MSMEs empowerment facilities in Batu. In the period 2016-2017, there were approximately 3500 MSMEs in Batu that collapsed and there were about 10.500 or $75 \%$ of MSMEs that could survive. Next, MSMEs cooperatives also suffered failure; at least there were approximately 80 MSMEs cooperatives in Batu that were defeated and then experienced bankruptcy in the period of 2017 - 2018. Other problems are also faced by the government of Batu that is related to the unemployment number that keeps increasing since 2012-2016.

This condition surely needs to be solved soon by the government of Batu. The commitment to make Batu become MSMEs center in line with the vision and mission of Batu must be followed with the policy that can give complete control in order to protect MSMEs sustainability and welfare in Batu. Empowerment that has been implemented involving different sectors through Quadruple helix model concept surely will not run well if it is not balanced with the government commitment as the party that has interaction domination to provide facilities, such as: well financed MSMEs cooperatives and apparatus resources; and to provide policies that really take small and medium enterprises' side. Quadruple helix model concept is empowerment media that focuses on human empowerment to minimize local economy gap. It also needs the government policy to guide MSMEs welfare in competing with big companies by making both of them as partners so there will not be any trade monopoly by big companies to MSMEs in Batu

\section{CONCLUSION}

The Department of Micro Enterprise Cooperatives and Trade of Batu implements MSMEs empowerment by relying on four main empowerment factors, they are: capital access, human resources, partnership, and market strengthening MSMEs empowerment is implemented in order to create fair and equitable economic development. In implementing MSMEs empowerment in Batu, there are four factors involved, they are: the government of Batu that is initiated by Department of Micro Enterprise Cooperatives and Trade of Batu, business/private parties, academics, and civil society that is initiated by Nongovernmental Organization,Communities, and the society of Batu entirely.

MSMEs empowerment based on Quadruple helix model concept gives benefits to solve basic problems in creating independent MSMEs through businessmen resources quality improvement, production quality improvement, marketing, information and technology utilization, and organizational strengthening. Besides, through the Quadruple helix model concept, there is a synergy pattern that results in roles of the actors involved in the empowerment process. The government plays a dominant role in synergizing the interactions among the sectors; and is responsible in the development of an equitable economy. Private parties play a role as a production developer. Academics play a role as a knowledge transferor and skill development. Civil society plays a role as creative economy agent, product consumer, organization supporter.

The strategies that can be conducted by the Local Government of Batu is implementing MSMEs empowerment strategy through Quadruple helix approach. The first, optimize Local Regulation and Mayor Regulation as instruments that can ensure MSMEs agents' welfare by not tolerating any monopoly conducted by private companies. The second, revitalize MSMEs cooperatives as a party/actor that contributes in MSMEs development through healthy financial resources. The third, optimize 
business roles in managing local products. It needs to be done because with the existence of business actors involved, it can increase investment value in Batu. However, what happens nowadays, Local Government tends to orientate on big scale companies and not on MSMEs empowerment. The fourth, MSMEs agents need to be more included in local products exhibitions in local or international events.The fifth, optimize IBSC building in order to improve businessmen knowledge; to improve products quality; and to tie a good relationship among businessmen in Batu. Finally,Use more modern information and technology. The Department of Micro Enterprise Cooperatives and Trade of Batu, especially SME division should repair and renew the data of MSMEs agents, so the government can provide assistance equitably and focus on Batik producers who really need assistance.

\section{REFERENCES}

Anomsari, E. T., \& Abubakar, R. R. T. (2019). Program Pembangunan Partisipatif Dan Dampaknya Terhadap Pemberdayaan Masyarakat. Jurnal Natapraja: Kajian Ilmu Administrasi Negara, 7(1), 121-138.

BPS Kota Batu. (2017). Batu Dalam Angka. BPS Kota Batu.

Dewi, R. T. (2009). Strategi dalam menumbuhkan dan mengembangkan usaha kecil dan menengah melalui pembinaan oleh dinas industri, perdagangan, koperasi dan penanaman modal di Kabupaten Ponorogo.

Effendi, B. (2002). Pembangunan Daerah Otonom Berkeadilan. Yogyakarta: Uhaindo Dan Offset.

Huberman, A. M., \& Saldana, J. (2014). Qualitative Data Analysis: A Methods Sourcebook. In R. R. Tjatep (Trans.), The SAGE Handbook of Applied Social Research Methods (3rd ed.). UI-Press.
Huraerah, A. (2008). Pengorganisasian dan pengembangan masyarakat: model \& strategi pembangunan berbasis kerakyatan. Humaniora.

Khamarullah, A. (2014). Strategi dan Dampak Pengembangan Usaha Mikro, Kecil, dan Menengah Berbasis Minapolitan (Studi pada Dinas Kelautan dan Perikanan Kabupaten Banyuwangi). Jurnal Administrasi Publik, 2(4), 591-596.

Moleong, L. J. (2006). Metode penelitian kualitatif edisi revisi. Bandung: Remaja Rosdakarya.

Mulyana, S. (2014). Peningkatan kapabilitas inovasi, keunggulan bersaing dan kinerja melalui pendekatan quadruple helix: studi pada industri kreatif sektor fashion. Jurnal Manajemen Teknologi, 13(3), 304-321.

Local Regulation of Batu Number 1, 2016, 19541 (2016).

Government Regulation No. 20/2008, UU No. 20 Tahun 20081 (2008).

Suryono, A. (2010). Dimensi-dimensi Prima Teori Pembangunan. UB Press.

Theresia, A. et. al. (2014). Pembangunan Berbasis Masyarakat. Alfabeta.

Zubaedi. (2007). Pengembangan masyarakat berbasis pesantren: kontribusi fiqh sosial Kiai Sahal Mahfudh dalam perubahan nilai-nilai pesantren. Pustaka Pelajar. 